\title{
DINAMIKA KONSUMSI ROKOK DAN IMPOR TEMBAKAU INDONESIA
}

\author{
Antik Suprihanti $^{1}$, Harianto $^{2}$, Bonar M. Sinaga ${ }^{2}$, Reni Kustiari ${ }^{3}$ \\ ${ }^{1}$ S3 Ekonomi Pertanian, Institut Pertanian Bogor, Indonesia \\ ${ }^{2}$ IPB Darmaga , Bogor, Indonesia \\ ${ }^{3}$ Litbang, Deptan, Indonesia \\ E-mail: antik.s@upnyk.ac.id
}

\begin{abstract}
The tobacco control and the danger of smoking campaigns have given quite much impact into the lower nicotine and tar cigarettes consumption pattern. This fact affects the higher demand of imported tobacco in which are believed to be better than locals. Object of this research are to analyze trend of Indonesian tobacco import in the next 3 years and analyze factors that influence Indonesian tobacco import. Method of the research used descriptive method which using time series secondary data for 27 years from 1990 to 2016. Data is taken from few institusions and literatures. Analysis method used linier trend and multiple linier regression. Results of this research indicate that from 2018 to 2020 import of Indonesian tobacco trend will increase about 3 percent every year. Consumption of cigarettes kretek industries, income and import tariff affect to Indonesian tobacco import significantly. The increasing of imported tobacco is caused by the high demand of virginia tobacco of cigarettes industries that increased their cigarettes production cause high consumption of mild (low nicotine and tar) cigarettes. Therefore, Indonesia government has to support tobacco's farmer in developing low nicotine and tar tobacco production that is needed by cigarettes industries through cooperation partnership with cigarettes producer, so the dependency of imported tobacco can be decreased.
\end{abstract}

Keywords: consumption, domestic production, import, tobacco

\begin{abstract}
Abstrak: Adanya pengendalian tembakau dan berbagai kampanye tentang bahaya merokok telah berdampak pada bergesernya pola konsumsi rokok ke jenis rokok yang mengandung rendah kadar nikotin dan tar. Hal ini berpengaruh pada tingginya permintaaan bahan baku tembakau impor yang dianggap lebih rendah kandungan nikotin dan tar-nya dibanding tembakau lokal. Penelitian ini bertujuan untuk menganalisis tren volume impor tembakau Indonesia hingga tahun 2020 yang akan datang, serta untuk menganalisis faktor-faktor apa yang mempengaruhi volume impor tembakau Indonesia. Penelitian ini menggunakan data sekunder dari tahun 1990 hingga tahun 2016 yang diambil dari berbagai lembaga serta literatur. Metode analisis menggunakan analisis trend serta regresi linier berganda. Hasil penelitian menunjukkan impor tembakau Indonesia tahun 2018-2020 diperkirakan meningkat rata-rata 3 persen per tahun. Jumlah konsumsi tembakau oleh pabrik rokok kretek, pendapatan penduduk, serta tarif impor tembakau berpengaruh signifikan terhadap volume impor tembakau Indonesia secara signifikan. Tren peningkatan impor ini terutama disebabkan oleh tingginya kebutuhan bahan baku tembakau untuk jenis tertentu (tembakau virginia) akibat peningkatan produksi rokok karena meningkatnya konsumsi rokok jenis mild (yang rendah nikotin dan tar). Oleh karena itu pemerintah Indonesia perlu mendorong petani tembakau lebih intensif mengusahakan jenis tembakau rendah nikotin dan tar yang dibutuhkan industri rokok melalui kerjasama kemitraan dengan produsen rokok sehingga ketergantungan terhadap impor dapat dikurangi.
\end{abstract}

Kata kunci : konsumsi, produksi domestik, tembakau, impor 


\section{PENDAHULUAN}

Dalam kerangka FCTC (Framework Convention on Tobacco Control), saat ini negara-negara maju giat melakukan kampanye untuk mengurangi konsumsi rokok dan penggunaan produk olahan tembakau. Kebijakan tersebut mengakibatkan terjadinya pergeseran konsumsi dan produksi produk tembakau, dari negara maju ke ke negara berkembang. Indonesia merupakan salah satu negara berkembang yang menjadi sasaran perpindahan tersebut (Rachmat, 2010).

Indonesia saat ini bahkan telah menjadi produsen sigaret sekaligus konsumen utama rokok. Menurut Tempo (2015), Indonesia menempati urutan keempat sebagai jumlah perokok terbanyak dunia setelah Cina, India dan Amerika Serikat. Konsumsi rokok Indonesia meningkat lebih dari dua kali lipat (dari 136 ke 293 milyar batang) antara tahun 1995-2013 seiring kenaikan jumlah perokok dan populasi penduduk dewasa (Ahsan et.al, 2014). Industri sigaret kretek umumnya terkonsentrasi di Jawa Timur dan Jawa Tengah, tetapi konsumsi rokok menyebar di seluruh pulau di Indonesia. Produksi sigaret kretek diperkirakan akan terus meningkat seiring dengan pertambahan jumlah penduduk Indonesia .

Selain itu, tidak adanya hambatan berarti untuk berkembangnya investasi asing terhadap produk olahan tembakau telah mengakibatkan industri sigaret Indonesia yang berstruktur oligopoli ini terus berkembang dan Indonesia sudah menjadi target pasar dari perusahaan sigaret transnasional. Indonesia bahkan memiliki potensi sebagai produsen utama rokok sigaret di dunia (Rachmat dan Aldillah, 2010). Perusahan transnasional rokok dunia seperti Philip Morris Internasional (PMI) masuk melalui akuisisi pabrik rokok nasional PT. HM. Sampurna. Pada tahun 2005 British American Tobacco (BAT) membeli PT Bentoel. Menurut Hurt et al (2011), strategi akuisisi dipilih karena memudahkan mereka untuk memasuki pasar rokok, di samping dapat memperbesar pengaruhnya terhadap kebijakan kesehatan di Indonesia. Perusahaan transnasional juga menggunakan strategi westernisasi pabrik kretek lokal untuk memperluas bisnis mereka. Tahun 2013, pangsa pasar HM Sampurna bahkan terus meningkat dan mampu melampaui perusahaan nasional seperti Gudang Garam dan Djarum (Barber et al, 2008).

Pengembangan industri rokok juga dicanangkan pemerintah melalui Perpres No.28 tahun 2008 tentang Kebijakan Industri Nasional, Industri Hasil Tembakau (IHT) dan Permenperin No. 117/M-IND/PER/10/2009 tentang Roadmap Pengembangan Klaster Industri Hasil Tembakau dan memasukkan industri ini sebagai salah satu industri prioritas untuk dikembangkan. Roadmap IHT tahun 2007-2020 memiliki 3 tahapan. Tahap 1 (20072010) prioritas pada aspek keseimbangan Tenaga Kerja, Penerimaan dan Kesehatan, Tahap 2 (2010-2014) prioritas pada aspek Penerimaan, Kesehatan dan Tenaga Kerja dan Tahap 3 (2015-2020) prioritas pada aspek Kesehatan melebihi aspek Tenaga Kerja dan Penerimaan. Kebijakan ini memberikan kesempatan untuk meningkatkan produksi $12 \%$ hingga tahun 2020.

Konsekuensi dari berkembangnya industri sigaret ini adalah semakin meningkatkan kebutuhan bahan baku tembakau untuk industri rokok. Menurut (Kemenperin, 2017) sekitar $97 \%$ produksi tembakau digunakan untuk industri rokok dan sangat sedikit yang digunakan untuk kebutuhan lain. Disisi lain, pemerintah juga menetapkan kebijakan yang terkait dengan kesehatan dan kebijakan cukai, yang diharapkan mampu menghambat meningkatnya konsumsi rokok Indonesia. Kebijakan tersebut tentunya akan berpengaruh terhadap kinerja industri rokok di Indonesia di Indonesia.

Data Kementrian perindustrian (Kemenperin) mencatat adanya pertumbuhan produksi rokok sekitar 5\% hingga 7,4\% per tahun. Pada tahun 2015 ini, Kemperin memprediksi produksi rokok mencapai 398,6 miliar batang, dan pada tahun 2016 diperkirakan naik sekitar 5,7\% yakni menjadi 421,1 miliar batang. Pada tahun 2020, diproyeksikan produksi mencapai 524,2 miliar batang. Jika jumlah produksi tembakau secara nasional hanya mencapai 190 ribu -200 ribu ton per tahun, sementara kebutuhan industri berkisar 360-400 ribu ton tembakau per tahun (untuk produksi 360-400 milyar batang rokok) maka sekitar 50 persen tembakau harus diimpor.

Berbagai kampanye bahwa konsumsi tembakau yang mengandung nikotin tar rendah 
lebih aman dikonsumsi saat ini telah mengakibatkan konsumen Indonesia, terutama kaum muda, mulai banyak yang beralih ke rokok jenis mild yang lebih ringan dan dianggap mengandung nikotin dan tar rendah. Namun rokok jenis mild ini membutuhkan jenis tembakau yang tidak dapat sepenuhnya dipenuhi oleh tembakau domestik, sehingga diperkirakan impor tembakau akan terus meningkat.

Sejak tahun 2008, impor tembakau terutama jenis virginia mulai meningkat dikarenakan ketersediaanya di dalam negeri kurang mencukupi. Menurut GAPPRI, sebanyak 50-55 persen kebutuhan tembakau virginia oleh pabrik rokok Indonesia merupakan tembakau impor. Tembakau jenis virginia direkomendasikan oleh WHO karena mempunyai kadar nikotin dibawah 2 persen. Penggunaan tembakau impor yang meningkat tentu dapat menggeser pangsa tembakau produksi Indonesia, terutama grade menengah ke bawah.

Produksi tembakau jenis virginia selama ini di Indonesia belum berkembang dengan baik mengingat kondisi iklim dan kondisi tanah Indonesia yang kurang sesuai untuk jenis tembakau ini. Hasil penelitian Nur dan Apriana (2013) mengindikasikan bahwa tembakau jenis virginia di Indonesia belum bisa diusahakan secara optimal baik dari sisi produktivitas maupun kontinuitasnya. Tembakau yang ada masih belum memiliki standar spesifikasi teknis yang dibutuhkan, akibatnya industri harus menanggung biaya grading ulang agar dapat dimanfaatkan secara benar dalam proses industri (Haryono, 2015).

Semakin meningkatnya impor tembakau, dapat menjadi salah satu faktor bagi pemerintah untuk menaikkan tarif impor tembakau. Tarif yang meningkat diharapkan dapat mengurangi konsumsi tembakau impor dan lebih meningkatkan konsumsi tembakau domestik. Upaya ini juga diharapkan akan meningkatkan produksi sigaret domestik tidak hanya untuk konsumsi domestik tetapi juga mendorong untuk ekspor (Suprihanti, 2016).

Secara teoritis permintaan impor suatu negara terhadap suatu barang merupakan kelebihan konsumsi yang tidak sanggup di produksi didalam negeri (Labys,1973). Suatu negara akan mengimpor karena produksi di negara pengimpor relatif kecil dibandingkan dengan konsumsinya. Menurut Kindleblenger dan Lindert (1982) permintaan impor dipengaruhi oleh harga impor, nilai tukar, pendapatan, dan kebijakan negara pengimpor. Dalam penelitian ini adalah kebijakan tarif impor tembakau.

Kebijakan tarif impor tembakau dimasukkan dalam model mengingat akan tarif mampu menjadi instrumen untuk mengurangi impor. Pemerintah berencana akan menaikkan tarif impor tembakau karena adanya kekhawatiran petani bahwa industri rokok Indonesia sudah sangat tergantung pada tembakau impor yang mengakibatkan tidak terserapnya tembakau petani lokal Indonesia. Namun, kebijakan kenaikan tarif impor masih ditunda mengingat pengusaha pabrik rokok keberatan akan rencana tersebut karena dianggap akan mengganggu kelangsungan produksi rokok. Hal ini dikarenakan kenaikan tarif impor akan berakibat kurangnya ketersediaan bahan baku tembakau yang diinginkan pabrik baik jumlah maupun kualitasnya.

Besar kecilnya impor tembakau Indonesia diduga dipengaruhi oleh konsumsi tembakau oleh industri rokok kretek, pendapatan penduduk, fluktuasi nilai tukar, harga tembakau dunia, serta kebijakan perdagangan seperti tarif impor tembakau. Permintaan tembakau oleh industri rokok diperhitungkan berdasarkan jumlah produksi rokok tiap-tiap jenis rokok kretek yang diperhitungkan dengan trend jumlah konsumsi rokok untuk tiap jenis rokok. Sementara jumlah konsumsi rokok sendiri berkorelasi positif dengan jumlah penduduk. Oleh karena itu variabel jumlah penduduk tidak peneliti masukkan dalam model penelitian.

Penelitian ini akan menelaah keterkaitan antara perubahan konsumsi rokok terhadap impor tembakau Indonesia. Bagaimana kecenderungan (trend) jumlah impor tembakau hingga tahun 2020 menyesuaikan roadmap yang disusun pemerintah terkait industri hasil tembakau. Volume impor tembakau Indonesia diduga selain dipengaruhi oleh konsumsi pabrik rokok kretek, pendapatan penduduk, harga tembakau dunia dan fluktuasi nilai tukar juga dipengaruhi oleh kebijakan perdagangan seperti tarif impor. Faktor-faktor apa saja yang mempengaruhi tingginya volume impor tembakau Indonesia penting untuk diteliti 
mengingat perubahan pola konsumsi rokok akan semakin nyata di masa depan.

Penelitian khususnya tentang impor tembakau dewasa ini belum banyak dianalisis. Penelitian umumnya dilakukan pada pasar tembakau dan industri rokok serta dampak kebijakan terhadap kontrol tembakau. Penelitian tentang pasar tembakau dilakukan oleh Maulidah dan Suryawijaya (2010), Hasan dan Dwidjono (2013), Rachmat dan Sri (2009), Rachmat (2010) dan Rachmat dan Aldillah (2010). Penelitian tentang daya saing tembakau lokal dilakukan oleh Hamidi (2007), dan Nur dan Apriana (2013). Penelitian pada industri rokok kretek yang diantaranya dilakukan oleh Wachjutomo (1996) dan Situmeang (2008), Irawan (1996), Harini (2001) dan Buana (2013) yang melihat dampak kebijakan pemerintah dan faktor eksternal terhadap industri rokok kretek Indonesia. Penelitian juga banyak dilakukan tentang dampak kebijakan kontrol tembakau, misalnya melalui kebijakan kenaikan pajak rokok dan kebijakan pembatasan iklan tembakau, terhadap perekonomian secara umum seperti penelitian di Afrika Selatan (Merwe, 1998), di Taiwan (Hsieh dan Lin, 1998), di Jepang (Nikahara dan Mochizuki, 1998), di Brazil (Silva, 1998) dan di Indonesia (Barber, et al, 2008).

Tujuan pertama penelitian untuk memprediksi impor tembakau hingga tahun 2020 yang akan datang, dan tujuan kedua untuk menganalisis pengaruh konsumsi tembakau oleh pabrik rokok kretek, pendapatan penduduk, harga tembakau dunia, fluktuasi nilai tukar, serta tarif impor terhadap volume impor tembakau di Indonesia. Penelitian ini menduga impor tembakau untuk tahun 2018 hingga 2020 akan meningkat. Impor yang meningkat tersebut diduga dipengaruhi oleh faktor jumlah konsumsi tembakau oleh pabrik rokok, pendapatan penduduk dan perubahan faktor-faktor ekonomi lainnya.

\section{METODE PENELITIAN}

Penelitian ini merupakan penelitian deskriptif, menggunakan data sekunder time series selama dari tahun 1990-2016. Data diperoleh dari Food and Agriculture Organization (FAO), UNComtrade, world bank, Badan Pusat Statistik (BPS), Direktorat Jenderal Perkebunan (Ditjenbun) dan berbagai literatur. Data meliputi jumlah konsumsi tembakau industri sigaret kretek, pendapatan penduduk, harga tembakau dunia, nilai tukar, tarif impor tembakau, serta volume impor tembakau. Data untuk tembakau yang diimpor dan yang dikonsumsi tidak membedakan jenisnya.

Model persamaan linier sederhana digunakan untuk mengetahui kecenderungan impor dan proyeksinya tiga tahun ke depan. Model yang digunakan adalah $\mathrm{QMTI}=\mathrm{a}+\mathrm{bT}$, di mana, QMTI adalah jumlah impor tembakau dan $\mathrm{T}$ adalah waktu (tahun). Konstanta dan koefisien dari model diwakili oleh a dan b.

Untuk menguji dugaan bahwa impor tembakau dipengaruhi oleh meningkatnya konsumsi bahan baku rokok dan faktor-faktor ekonomi lainnya, termasuk kebijakan pemerintah, digunakan model regresi linier berganda (multiple linier regression). Metode analisis regresi linier berganda ini merupakan analisis yang bersifat kuantitatif untuk melihat sejauhmana besarnya pengaruh antara variabel bebas terhadap variabel terikat. Untuk menganalisis faktor-faktor yang mempengaruhi jumlah impor tembakau disusun persamaan sebagai berikut:

$\mathrm{QMTI}=\mathrm{a}+\mathrm{b}_{1} \mathrm{CTSKI}+\mathrm{b}_{2} \mathrm{GDP}+\mathrm{b}_{3} \mathrm{PTW}+$ $\mathrm{b}_{4} \mathrm{NT}+\mathrm{b}_{5} \mathrm{TIT}+\mathrm{e}$

di mana:

QMTI = jumlah impor tembakau Indonesia (ton)

CTSKI $=$ jumlah konsumsi tembakau industri sigaret kretek (ton)

GDP = pendapatan penduduk Indonesia (juta US\$/kapita)

PTW = harga tembakau dunia (US\$ $/ \mathrm{kg}$ )

NT = nilai tukar Rupiah terhadap Dolar Amerika (Rp/US\$)

TIT = tarif impor tembakau (\%)

a $\quad=$ intersep / konstanta

$\mathrm{b} \quad=$ koefisien

$\mathrm{e} \quad=$ error

\section{HASIL DAN PEMBAHASAN}

Rokok yang diproduksi di Indonesia terbagi atas 2 macam, yaitu rokok kretek dan rokok putih. Rokok kretek merupakan jenis rokok yang mayoritas diproduksi di Indonesia, yaitu sebesar 93,10 persen (Rahmat, 2010). Perbedaan rokok kretek dan rokok putih 
terletak pada ada tidaknya kandungan cengkeh. Rokok kretek merupakan rokok tradisional khas Indonesia yang dibuat dari tembakau, kuncup cengkeh dan bumbu 'saus'. Rokok kretek diproduksi dengan menggunakan tangan (manual) atau pun dibuat dengan menggunakan mesin. Sementara itu rokok putih umumnya dibuat dengan mesin, dan tidak menambahkan cengkeh sebagai salah satu bahan utamanya. Jenis rokok lainya yaitu klobot dan cerutu juga diproduksi tetapi pangsanya relatif sangat kecil. Rokok kretek meliputi sigaret kretek tangan (SKT) dan sigaret kretek mesin (SKM). Jenis SKM yang diproduksi termasuk di dalamnya rokok mild, baik yang menggunakan filter maupun non-filter.

\section{Produksi dan Konsumsi Rokok Kretek Indonesia}

Produksi rokok nasional cenderung mengalami peningkatan. Data Kemenkeu (2016) menunjukkan bahwa produksi tembakau tahun 2010- 2015 meningkat sekitar 346,5 milyar batang pada 3 tahun terakhir. Gambar 1 menunjukkan perkembangan produksi rokok di Indonesia sejak tahun 1990 hingga 2016. Terlihat produksi rokok kretek Indonesia tumbuh dengan laju pertumbuhan yang lambat sebelum tahun 2008. Namun, setelah tahun 2008, produksi rokok Indonesia mulai meningkat hingga tahun 2015, dan kemudian namun sedikit menurun pada tahun 2016.

Perkembangan produksi rokok SKM cenderung lebih cepat daripada SKT, karena beberapa faktor seperti gencarnya promosi rokok SKM dibanding SKT. Produksi rokok
SKM yang meningkat lebih cepat daripada SKT juga mencerminkan telah terjadinya perubahan pola konsumsi rokok. Banyak konsumen yang memilih rokok kretek yang lebih ringan terutama SKM yang berlabel light dan mild karena dianggap memiliki efek negatif tembakau yang minimum. Data Ditjen Bea Cukai menunjukkan bahwa dari tahun 20092013, pangsa pasar SKT turun 20,5 persen, sementara SKM naik 11,7 persen khususnya jenis mild (Suprihanti, 2016). Pergeseran pola konsumsi perokok dari rokok SKT ke rokok SKM kemungkinan besar disebabkan gencarnya iklan dan promosi perusahaanperusahaan sigaret skala besar bahwa rokok jenis mild lebih rendah kandungan nikotin dan tar-nya daripada rokok kretek tangan.

Permintaan rokok terus meningkat seiring dengan pertambahan jumlah penduduk. Proporsi konsumsi rokok didominasi oleh rokok kretek yang mencapai 90 persen pada tahun 1990-2010 (BPS, 2012) dan mayoritas konsumen domestik. Data BPS dan Kementrian Kesehatan (2015) mencatat bahwa proporsi perokok (merokok setiap hari) dari tahun 20072013 meningkat 23,7 persen sampai 24,3 persen. Data Nielsen (2014) menunjukkan bahwa permintaan rokok sepanjang tahun 2014 sebesar 201,24 milyar batang. Dari jumlah tersebut, sekitar 78 persen permintaan rokok SKM, sisanya 22 persen rokok SKT. Permintaan rokok SKM terdiri dari tiga kelompok yaitu rokok SKM light dan mild (SKMLM), SKM full flavour (SKMFF), dan sigaret putih mesin (SPM).

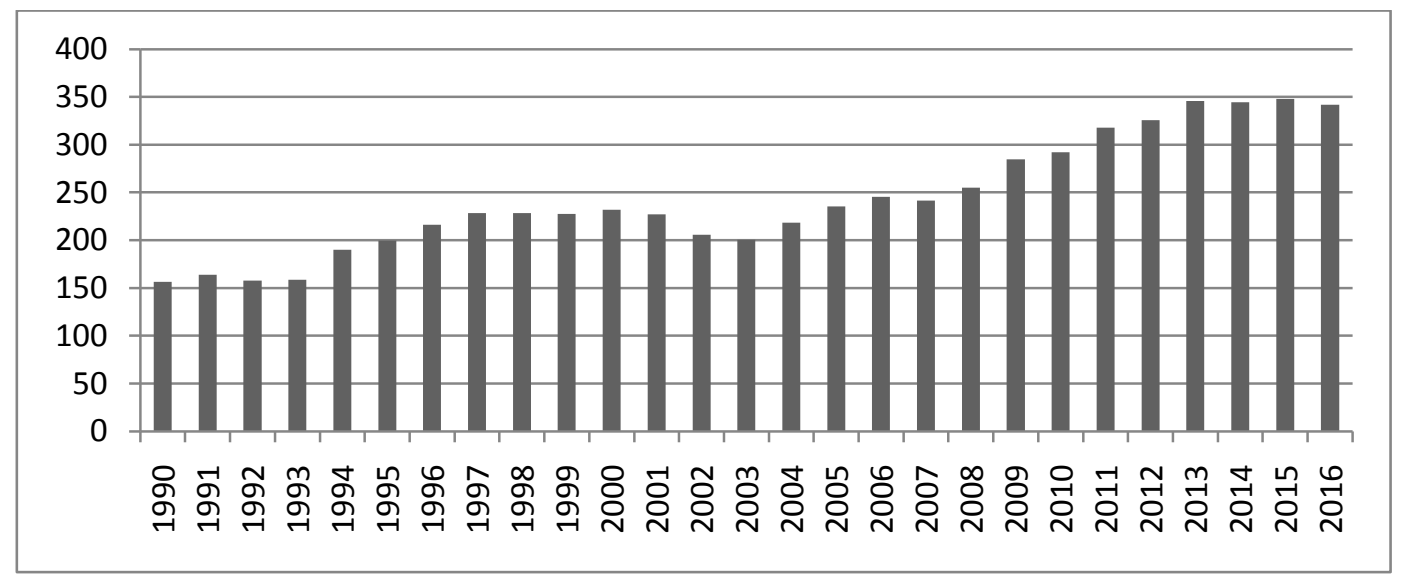

Gambar 1. Perkembangan Produksi Kretek 1990-2016 (milyar batang) Sumber: Ditjen Bea Cukai (Kemenkeu) 
Wilayah produksi utama tanaman tembakau di Indonesia adalah Jawa Timur, Jawa Tengah, Jawa Barat, dan Nusa Tenggara Barat. Dari keseluruhan tanaman tembakau yang diusahakan di Indonesia hampir keseluruhannya diusahakan oleh pertanian rakyat skala kecil. Data Ditjenbun (2014) menunjukkan bahwa luas tanam tembakau pertanian rakyat selama tahun 2006-2013 ratarata mencapai 98,2 persen dari total luas tanam tembakau Indonesia.

Rokok kretek dibuat dengan menambahkan cengkeh dan "saus" selain tembakau sebagai bahan baku utamanya. Tembakau yang ditanam di Indonesia memiliki banyak jenis dan tiap jenis beda penggunaannya. Tembakau deli, tembakau vorstenland dan tembakau besuki merupakan tembakau cerutu sedangkan tembakau lumajang merupakan tembakau pipa. Untuk pembuatan rokok yang banyak dipakai adalah tembakau virginia, oriental dan burley. Tembakau oriental digunakan sebagai campuran di hampir semua pabrik rokok karena memiliki aroma khas dan sekaligus dapat meningkatkan mutu.

Tembakau rajang/Jawa merupakan jenis yang paling banyak diproduksi dengan banyak jenis tergantung daerah produksi. Perkembangan luas tanam tembakau di wilayah produksi utama di Indonesia ditunjukkan pada Tabel 1. Tembakau rajang mendominasi produksi tembakau selain tembakau virginia dan jenis tembakau lainnya (asepan, garangan, paiton, vike, kasturi, madura, dan white burley).

\section{Impor Tembakau}

Impor tembakau dilakukan karena produksi dalam negeri tidak mampu mencukupi kebutuhan industri sigaret. Dari data UNComtrade selama 10 tahun terakhir menunjukkan total impor tembakau Indonesia, sebagian besar (lebih dari 50 persen) berasal dari China, sedangkan sisanya diimpor dari Brazil, Amerika Serikat dan India. Tembakau yang diimpor umumnya adalah virginia, oriental dan burley. Namun jenis tembakau virginia yang paling banyak diperlukan sebagai bahan campuran dalam produksi rokok kretek (GAPPRI). Kurangnya produksi jenis tembakau ini ditunjukkan dari data Ditjenbun yang menunjukkan bahwa lahan yang diusahakan untuk jenis tembakau virginia kurang dari 20 persen dari total lahan yang ditanami tembakau di daerah sentra tembakau (Tabel 1).

Data impor tembakau Indonesia dari tahun 1990-2016 menunjukkan bahwa impor tembakau berfluktuasi dengan kecenderungan yang semakin meningkat. Impor tembakau mulai tahun 2005 mencapai lebih dari 38 ribu ton dengan trend yang semakin naik (Gambar 2). Impor tembakau paling rendah terjadi saat pertumbuhan ekonomi mengalami penurunan signifikan (krisis), yaitu tahun 1997/1998.

Impor tembakau yang tinggi pada sejak tahun 2005 hingga thun 2016 diperkirakan terjadi karena masuknya investasi asing pada tahun 2005 ke industri rokok di Indonesia, baik melalui akuisisi maupun peningkatan kapasitas produksi. Pasar yang semakin berkurang di negara maju serta berbagai kampanye untuk mengurangi konsumsi tembakau telah mengakibatkan perusahaan besar mengembangkan pasarnya di Indonesia. Dengan strategi westernisasinya dengan promosi produk yang gencar, dan didukung oleh adanya kampanye nasional dan dunia terhadap bahaya rokok yang tinggi kandungan nikotin dan tar, menjadikan konsumsi rokok jenis mild semakin meningkat terutama dikalangan perokok pemula. Akibatnya, bahan baku yang dibutuhkan untuk produksi rokok jenis mild juga semakin meningkat. Bahan baku yang berasal dari tembakau impor sering diklaim memiliki kadar nikotin dan tar yang rendah.

Tabel 1. Perkembangan luas tanam tembakau di Indonesia menurut Jenisnya (\%)

\begin{tabular}{lrrr}
\hline Jenis & Tahun 2011 & Tahun 2013 & Tahun 2015 \\
\hline Rajang/Jawa & 37,6 & 41,2 & 41,7 \\
Virginia & 18,2 & 18,5 & 13,9 \\
Lainnya & 36,6 & 29,2 & 34,2 \\
\hline Sumber: Ditjenbun (diolah) & & &
\end{tabular}


Antik S., Harianto, Bonar M S., Reni K.: Dinamika Konsumsi Rokok dan ...

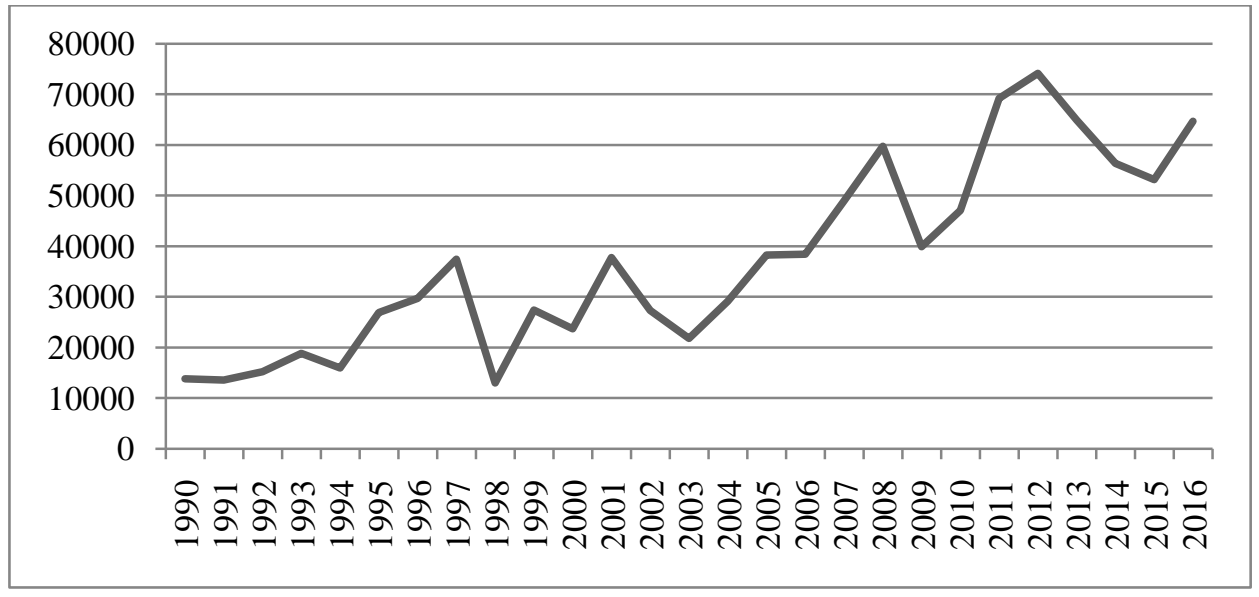

Gambar 2. Perkembangan Impor Tembakau Tahun 1990-2016 (ton)

Sumber: UN Comtrade.com

Tabel 2. Kandungan Tar dan Nikotin Rokok Kretek dan Konvensional Amerika

\begin{tabular}{lcc}
\hline Kandungan & Rokok Kretek Indonesia & Rokok Konvensional Amerika \\
\hline Tar,mg & 46,8 & 16,3 \\
Nikotin,mg & 2,2 & 1,1 \\
\hline
\end{tabular}

Sumber: Nadel, et al (2005)

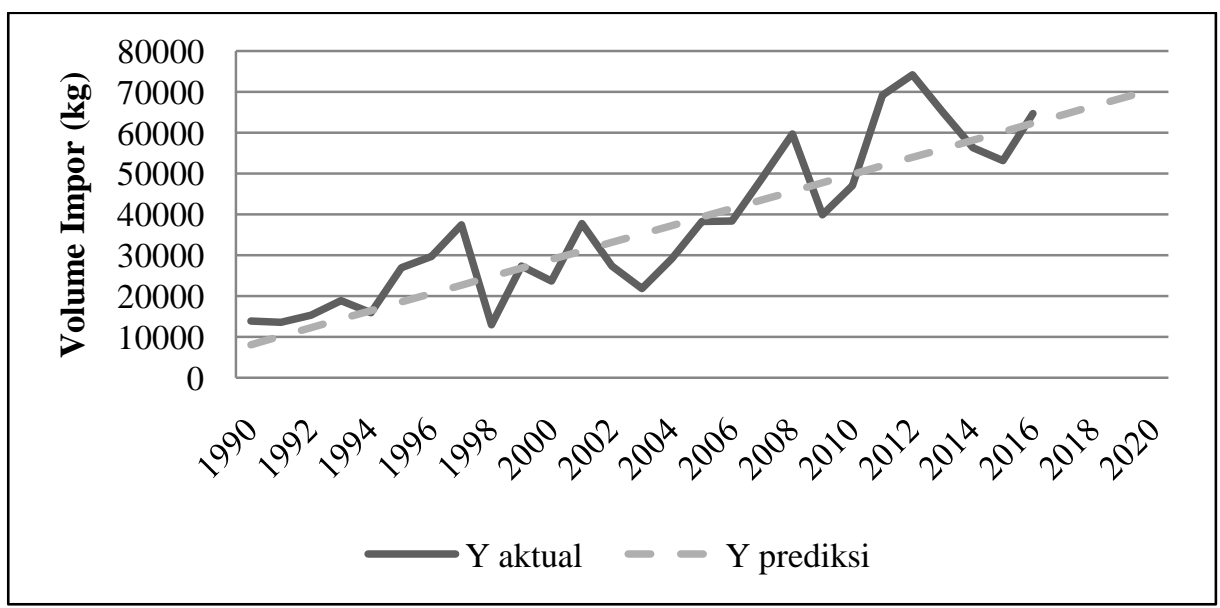

Gambar 3. Trend Impor Tembakau (aktual dan prediksi)

Penelitian Nadel, et al (2005) pada Tabel 2. menunjukkan bahwa kandungan tar dan nikotin per batang rokok yang terkandung dalam rokok kretek Indonesia tergolong tinggi dibandingkan jenis rokok putih (konvensional Amerika). Tembakau yang banyak dipakai untuk produksi rokok di Amerika adalah jenis tembakau Virginia.

Penelitian ini menunjukkan bahwa impor tembakau Indonesia memang cenderung meningkat relatif besar per tahunnya. Persamaan trend linier yang diperoleh adalah:

$$
\mathrm{QMTI}=8094,409+2084,537 \mathrm{~T}
$$

Gambar 3 menyajikan hasil perkembangan impor tembakau Indonesia aktual dengan impor tembakau berdasarkan model trend linier yang diperoleh. Hasil prediksi dengan analisis trend linier (Gambar 3) menunjukkan bahwa kedepan volume impor tembakau akan terus naik. Peramalan impor hingga tahun 2020 disesuaikan dengan roadmap industri hasil tembakau yang dicanangkan pemerintah. Hasil peramalan 
untuk tahun 2018, 2019, dan 2020 dengan menggunakan data-data sebelumnya dapat dilihat pada Tabel 3. Pertumbuhan impor Volume impor diperkirakan bahwa impor tembakau Indonesia di masa depan akan terus meningkat sebesar 3 persen per tahun menjadi sebesar 72,7 ribu ton tembakau di tahun 2020 .

\section{Faktor-faktor yang Mempengaruhi Impor} Tembakau Indonesia.

Sebelum melakukan analisis regresi, peneliti melakukan beberapa uji untuk memenuhi asumsi-asumsi umum dalam analisis regresi linier yang meliputi uji normalitas, uji multikolinieritas, uji autokorelasi dan uji heteroskedastisitas. Hasil pengujian menunjukkan bahwa data yang digunakan terdistribusi normal. Secara umum tidak terjadi gejala multikolinieritas di antara semua variabel bebas lainnya. Uji autokorelasi menggunakan nilai Durbin Watson (DW). Nilai DW hasil perhitungan diperoleh sebesar 2,131, sedangkan nilai DW tabel adalah 1.75 di mana berdasarkan kriteria pengujian maka model dinyatakan tidak ada masalah autokorelasi. Model penelitian juga telah memenuhi asumsi heteroskedastitas.

Hasil analisis faktor-faktor yang mempengaruhi volume impor tembakau
Indonesia dapat dilihat pada Tabel 4. Hasil regresi menunjukkan bahwa variabel konsumsi tembakau oleh industri sigaret kretek, pendapatan serta tarif impor berpengaruh nyata terhadap volume impor tembakau. Sementara harga tembakau dunia dan nilai tukar tidak berpengaruh signifikan terhadap jumlah impor tembakau Indonesia. Hasil analisis menunjukkan nilai $\mathrm{F}$ hitung sebesar 28,697 dengan tingkat signifikansi 0.000 . Hal ini berarti variabel bebas mempunyai pengaruh secara bersama-sama terhadap variabel terikat (volume impor tembakau). Nilai $\mathrm{R}^{2}$ sebesar 0,87 menunjukkan bahwa 87,2 persen dari keragaman variabel impor tembakau (QMTI) dapat dijelaskan oleh variabel bebas dalam model sedangkan sisanya (12,8 persen) dipengaruhi oleh variabel lain yang tidak dimasukkan dalam model.

Fenomena persaingan antar perusahaan rokok yang tinggi dalam perebutan pangsa pasar sigaret kretek SKM mild di Indonesia dapat dilihat dari variabel jumlah konsumsi tembakau industri sigaret kretek (CTSKI) yang berpengaruh sangat nyata terhadap jumlah impor tembakau. Jumlah konsumsi tembakau oleh industri sigaret kretek terkait erat dengan jumlah konsumsi rokok.

Tabel 3. Prediksi Volume Impor Tembakau Indonesia Tahun 2018-2020

\begin{tabular}{cc}
\hline Tahun & Volume Impor (ton) \\
\hline 2018 & 68,546 \\
2019 & 70,631 \\
2020 & 72,715 \\
\hline
\end{tabular}

Sumber: Hasil olah data sekunder

Tabel 4. Faktor-faktor yang mempengaruhi jumlah impor tembakau Indonesia

\begin{tabular}{lrrr}
\hline & koefisien & standard error & sig \\
\hline Intersep & 2985 & 14249 & 0,839 \\
Konsumsi tembakau $(\mathrm{CTSKI})^{* * *}$ & 0,295 & 0,163 & 0,086 \\
Pendapatan penduduk (GNP) $^{*}$ & 14,162 & 10,049 & 0,173 \\
Harga tembakau dunia (PTW) $^{\mathrm{ns}}$ & -3857 & 3312 & 0,257 \\
Nilai Tukar (NT) $^{\mathrm{ns}}$ & $-0,646$ & 0,97 & 0,513 \\
Tarif Impor tembakau (TIT) $^{* *}$ & -3334 & 2069 & 0,122 \\
\hline
\end{tabular}

\begin{tabular}{ll}
\hline $\mathrm{R}^{2}=0,872$ & Adj $\mathrm{R}^{2}=0,842$ \\
$\mathrm{DW}=2,131$ & $\mathrm{~F}$ hitung $=28,697$ \\
$* * *=$ signifikan pada alfa $10 \%$ & \\
$* *=$ signifikan pada alfa $15 \%$ & \\
$*=$ signifikan pada alfa $20 \%$ & \\
$\mathrm{~ns}=$ tidak signifikan &
\end{tabular}


Perusahaan sigaret kretek umumnya tidak menyimpan stok rokok siap konsumsi dalam jumlah banyak dan dalam waktu lama, karena penyimpanan yang lama akan berakibat pada penurunan kualitas atau "kesegaran" rokok.

Peningkatan jumlah konsumsi rokok harus mampu dipenuhi oleh perusahaan rokok. Jika produksi suatu perusahaan tidak mampu memenuhi peningkatan permintaan, maka risiko untuk kehilangan pangsa pasar baik pasar domestik maupun pasar ekspor akan tinggi. Sedangkan perusahaan rokok kretek telah mengeluarkan anggaran yang relatif besar dalam bentuk promosi untuk mempertahankan dan menambah pangsa pasarnya, sehingga ketidak mampuan memenuhi peningkatan permintaan dapat berakibat besar terhadap daya saing perusahaan rokok sigaret di Indonesia. Dengan keterbatasan pasokan tembakau virginia yang bersumber dari produksi dalam negeri, maka impor merupakan jalur tercepat untuk menutupi pasokan bahan baku yang kurang.

Variabel harga tembakau dunia (PTW) serta nilai tukar Rupiah (NT) ternyata tidak berpengaruh nyata pada jumlah impor tembakau walaupun tanda parameter sesuai harapan. Jika perusahaan mengalami kekurangan bahan baku impor, perusahaan rokok tetap akan mengimpor saat harga tembakau internasional meningkat dan nilai tukar melemah walau dalam jumlah impor yang kurang signifikan. Bagi perusahaan rokok lebih menguntungkan untuk tetap mengimpor untuk menutupi kekurangan bahan bakunya daripada kehilangan pangsa pasar karena produksi berkurang.

Dari hasil regresi yang menunjukkan bahwa tarif impor (TIT) berpengaruh nyata terhadap jumlah impor tembakau. Tarif impor pada dasarnya akan berakibat pada meningkatnya harga tembakau yang harus dibayar oleh perusahaan rokok. Hasil analisis menunjukkan bahwa TIT cukup efektif dalam mengurangi impor tembakau. Namun dalam aplikasinya kenaikan tarif impor masih menimbulkan perdebatan di kalangan pengusaha rokok. Saat ini tarif impor tembakau masih dikategorikan rendah $(5 \%)$ mengingat masih tingginya kebutuhan tembakau impor untuk industri rokok di dalam negeri. Ketentuan pembatasan impor tembakau yang sudah dibuat pemerintah pun harus ditunda mengingat belum siapnya ketersediaan tembakau di dalam negeri. Impor tembakau masih sangat diperlukan mengingat industri hasil tembakau harus memenuhi kapasitas produksinya agar bisa tetap menguntungkan dan tetap bertahan sehingga ketersediaan bahan baku harus cukup dan kontinu. Kurangnya bahan baku akibat ketersediaan bahan baku lokal yang terbatas dapat mengganggu kelangsungan produksi indutri ini.

Pada situasi saat ini, impor tembakau dari luar negeri diperkirakan bukan sepenuhnya substitusi bagi tembakau yang dihasilkan oleh petani dalam negeri. Oleh karena itu, perusahaan-perusahaan rokok kemungkinan mengimpor tembakau untuk menutupi kekurangan bahan baku tembakau yang tidak dapat sepenuhnya dapat diperoleh dari produksi dalam negeri. Pada kenyataannya, produksi tembakau yang diimpor tersebut di dalam negeri kurang berkembang misalnya saja luas tanam tembakau virginia yang cenderung relatif stabil tahun 2011 bahkan menurun pada tahun 2015 sementara permintaannya cenderung terus meningkat.

Hasil penelitian ini sejalan dengan penelitian Wachjutomo (1996) yang mengindikasikan bahwa variabel jumlah konsumsi industri sigaret kretek berpengaruh nyata terhadap volume impor sementara harga impor tidak berpengaruh signifikan. Nilai tukar juga tidak berpengaruh nyata terhadap jumlah impor sementara penelitian sebelumnya menunjukkan bahwa nilai tukar berpengaruh signifikan terhadap impor. Hasil penelitian ini hampir sama dengan penelitian Situmeang (2008) yang mengindikasikan bahwa variabel jumlah konsumsi industri sigaret kretek berpengaruh nyata, sedangkan variabel nilai tukar dan harga impor tidak berpengaruh nyata terhadap volume impor.

Perbedaan hasil penelitian ini dengan penelitian terdahulu dikarenakan perbedaan komoditas dimana Wahjutomo dan Situmeang meneliti komoditas cengkeh sebagai bahan baku industri sigaret kretek sedangkan penelitian ini meneliti bahan baku tembakau. Pada komoditas cengkeh, karena cengkeh impor sifatnya substitute dengan cengkeh lokal, maka ketersediaan stok cengkeh di dalam negeri tentu akan mengurangi impor cengkeh. Dalam penelitian ini karena bahan baku rokok kretek merupakan campuran antara tembakau 
impor dan tembakau lokal, maka kenaikan produksi rokok akan mengakibatkan kenaikan konsumsi tembakau impor selain tembakau lokal. Kenaikan tembakau impor akan semakin besar seiring dengan pertumbuhan produksi rokok khususnya jenis mild. Impor akan terus meningkat jika tembakau impor yang tersedia (stok) didalam negeri tidak mencukupi kebutuhan pabrik rokok domestik.

Meningkatnya pendapatan penduduk berpengaruh positif dan signifikan terhadap tingginya impor tembakau. Hal ini mengindikasikan bahwa semakin tinggi pendapatan penduduk suatu negara, semakin meningkatkan kemampuan daya beli penduduk sehingga konsumsipun meningkat termasuk untuk membeli rokok. Hal ini sejalan dengan penelitian Kindleblenger dan Lindert (1982) bahwa permintaan impor dipengaruhi oleh pendapatan penduduk. Data BPS dan Kemenkes, serta Kemenperin juga menunjukkan bahwa telah terjadi peningkatan jumlah perokok di Indonesia setiap tahunnya. Pangsa pasar rokok juga telah mengalami pergeseran dari rokok SKT konvensional ke jenis rokok kretek yang lebih ringan terutama SKM yang berlabel light dan mild karena dianggap memiliki efek negatif minimum. Hal ini ditunjukkan dengan turunnya pangsa pasar SKT sebesar 20,5 persen, sementara SKM naik 11,7 persen khususnya jenis mild (Suprihanti, 2016). Konsekuensi dari hal tersebut adalah meningkatnya permintaan tembakau impor untuk memproduksi jenis rokok jenis ini.

Dari hasil penelitian ini terlihat bahwa tingginya konsumsi rokok jenis mild selama beberapa tahun terakhir ini telah mengakibatkan perubahan komposisi bahan baku rokok yang berdampak pada peningkatan permintaan tembakau impor jenis tertentu. Sementara produksi tembakau substitusi impor yang memang belum berkembang baik di Indonesia karena wilayah dan kondisi alam dan tanah di Indonesia mengakibatkan terbatasnya produksi tembakau ini. Impor yang dilakukan belum pada taraf untuk substitusi tembakau produksi dalam negeri, dalam artian perusahaan mengimpor karena memang pasokan dari domestik masih kurang.

Pengembangan tembakau jenis virginia di Indonesia masih terbatas dilakukan di daerah di Jawa Timur dan Lombok (Nusa tenggara Barat). Penelitian Hamidi (2007) mengindikasikan bahwa pengembangan usahatani tembakau virginia di Lombok efisien untuk memenuhi kebutuhan dalam negeri namun tidak untuk ekspor. Penelitian Nur dan Apriana (2013) menunjukkan bahwa tembakau virginia yang ditanam di Bojonegoro (Jawa Timur) dan di Lombok Timur kurang kompetitif dan mempunyai kualitas yang relatif rendah dibandingkan produk sejenis dari impor.Indonesia justru dikenal sebagai penghasil tembakau dengan kandungan nikotin dan tar yang tinggi. Tembakau jenis ini kebanyakan diekspor sebagai bahan baku rokok cerutu yang berkualitas tinggi.

Kebutuhan tembakau impor untuk konsumsi industri rokok yang terus meningkat ini harus diantisipasi segera agar pabrikan rokok Indonesia tidak selalu mengandalkan impor. Hal ini ditunjukkan dari tingginya konsumsi tembakau oleh pabrik rokok kretek dengan sangat signifikan. Pengembangan dan penelitian jenis tembakau khususnya tembakau impor yang rendah nikotin dan tar seperti virginia selama ini kurang berkembang karena minimnya bimbingan kepada para petani. Oleh karena itu diperlukan upaya budidaya yang efektif dan efisien dengan bimbingan teknis dan tersedianya varietas unggul untuk meningkatkan daya saing tembakau Indonesia terutama untuk pasar domestik. Bentuknya adalah dengan melakukan kerjasama kemitraaan antara petani dengan produsen rokok, sehingga ketersediaan bahan baku tembakau untuk pabrik rokok juga terjaga dan mengurangi ketergantungan pada tembakau impor. Apabila ketersediaan tembakau impor yang ditanam di dalam negeri mencukupi maka rencana kebijakan kenaikan tarif impor tembakau atau pembatasan tembakau impor bisa diaplikasikan untuk menekan tingginya impor tembakau.

\section{KESIMPULAN DAN SARAN}

\section{Kesimpulan}

Berdasarkan pada hasil penelitian, maka dapat disimpulkan bahwa impor tembakau Indonesia di masa depan akan terus meningkat sebesar 3 persen per tahun. Jumlah konsumsi tembakau oleh pabrik rokok kretek berpengaruh sangat nyata terhadap volume impor tembakau Indonesia selain faktor pendapatan penduduk dan tarif impor tembakau. Peningkatan volume 
impor ini terutama untuk mengisi kekurangan industri rokok akan bahan baku tembakau jenis tertentu (tembakau virginia) yang disebabkan oleh peningkatan produksi rokok karena konsumsi rokok terutama jenis mild yang terus meningkat akibat naiknya pendapatan.

\section{Saran}

Untuk mengurangi ketergantungan impor, pemerintah perlu mendorong petani tembakau untuk lebih intensif mengembangkan jenis tembakau rendah nikotin dan tar di daerah lain di Indonesia yang sesuai untuk komoditas tersebut. Peningkatan produksi tembakau untuk jenis yang dibutuhkan oleh perusahaan dapat dilakukan diantaranya dengan pola kerjasama kemitraan antara petani dengan produsen rokok.

\section{DAFTAR PUSTAKA}

Ahsan, et.al. Illicit Cigarette Consumption and Government Revenue Loss in Indonesia. DOI: 10.1186/s12992-014-0075-7.

Barber S, Adioetomo SM, Ahsan A, Setyonaluri D. 2008. Tobacco Economics in Indonesia. Paris: International Union Against Tuberculosis and Lung Disease.

BPS and Kemenkes RI. 2015. Perilaku Merokok Masyarakat Indonesia. Pusat Data dan Informasi Kementrian Kesehatan Infodatin. Diakses pada 22 Maret 2016.

Buana, A S. 2013. Pengaruh Kenaikan Tarif Cukai Rokok Kretek Terhadap Harga, Penawaran dan Permintaan Komoditas Rokok Kretek dan Komoditas Tembakau serta Kesejahteraan Masyarakat. Skripsi. Institut Pertanian Bogor.

Direktorat Jenderal Perkebunan. 2012. Statistik Perkebunan Indonesia: Komoditas Tembakau 2011-2013. Jakarta.

.2014. Statistik Perkebunan Indonesia: Komoditas Tembakau 2013-2015. Jakarta.
.2016. Statistik Perkebunan Indonesia: Komoditas Tembakau 2015-2017. Jakarta.

Hasan, F dan Dwidjono HD. 2013. Prospek dan Tantangan Usahatani Tembakau Madura. Jurnal SEPA. 10 (1): 63 - 70.

Harini, S. (2001). Dampak Kebijakan Pemeritah terhadap Keragaan Industri Rokok Kretek Indonesia. Tesis. Institut Pertanian Bogor. Retrieved from http://repository.ipb.ac.id

Haryono, Imam. 2015. Road Map 2007-2020. Industri Hasil Tembakau dan Kebijakan Cukai (Departemen: Perindustrian, Perdagangan, Keuangan, Kesehatan, Pertanian, Tenaga Kerja dan Transmigrasi, serta Gappri, dan Gaprindo). Balittas.doc.

Hurt, Richard D, Jon O Ebbert, Anhari Achadi, Ivana T Croghan. 2011. Roadmap to a tobacco epidemic: transnational tobacco companies invade Indonesia. Research paper. Tobacco Control May 2012. 21 (3): 306-312

Hamidi, H. 2007. Daya Saing Tembakau Virginia Lombok di Pasar Ekspor. Agroteksos, 17 (2): 129-133.

Irawan, E. 1996. Analisis Dampak Penetapan Cukai terhadap Industri Tembakau Indonesia. Disertasi. (unpublished). Institut Pertanian Bogor.

Kemenperin (2017). Kemenperin.go.id. Produksi Tembakau Siap Bangkit. http://www.kemenperin.go.id/artikel /13782/\%20 Produksi-Tembakau-SiapBangkit

Kindleberger, C.P., and D.H. Lindert. 1982. International Economics. Richard D. Irwin, California.

Labys, WC. 1973. Dynamic Commodity Models: Spesification, Estimation and Simulation. D.C Helt and Company, Lexington. 
Maulidah, S dan Suryawijaya, TA. 2010. Analisis Penawaran dan Permintaan Tembakau (Nicotiana sp.). Jurnal SEPA, 7 (1): 39-50.

Merwe, R. 1998. The Economics of Tobacco Control in South Africa dalam Abedian I, $\mathrm{R}$ van der Merwe, N. Wilkins and P.Jha (eds.), Handbook: The Economics of Tobacco Control, Towards an Optimal Policy Mix.. Applied Fiscal Research Centre, Universitas Cape Town. EdsonClyde Press, Mowbray, W.Cape. : 251271.

Nadel, J. Rees.V dan Cooolly.G.N. 2005. Disparities in Global Tobacco Harm Reduction. Letter on American Journal of Public Health. 95 (12): 2120 .

Nikahara, T dan Yumiko M. 1998. The Economics of Tobacco Control in Japan dalam Abedian I, R van der Merwe, N. Wilkins and P.Jha (eds.), Handbook: The Economics of Tobacco Control, Towards an Optimal Policy Mix.. Applied Fiscal Research Centre, Universitas Cape Town. Edson-Clyde Press, Mowbray, W.Cape. : 330-335.

Nur, Y H dan D. Apriana. 2013. Daya Saing Tembakau Virginia Lokal di Pasar Dalam Negeri (Competitiveness of Local Virginia Tobacco in Domestic Market). Buletin Ilmiah Litbang Perdagangan. 7(1): 73-89.

Rachmat, M dan S. Nuryanti. 2009. Dinamika Agribisnis Tembakau Dunia dan Implikasinya bagi Indonesia. Forum Penelitian Agro Ekonomi. 27 ( 2) : 73 91.

Rachmat, M. 2010. Pengembangan Ekonomi Tembakau Nasional: Kebijakan Negara Maju dan Pembelajaran Bagi Indonesia. Jurnal Analisis Kebijakan Pertanian. 8 (1): 67-83.

Rachmat, M dan Aldillah, R. 2010. Agribisnis Tembakau di Indonesia: Kontroversi dan Prospek. Jurnal Forum Penelitian Agro Ekonomi. 28(1): 69-80.
Silva, V L C. 1998. The Brazillian Cigarette Industry: Prospects for Consumption Reduction. dalam Abedian I, R van der Merwe, N. Wilkins and P.Jha (eds.), Handbook: The Economics of Tobacco Control towards an optimal policy mix. Applied Fiscal Research Centre, Universitas Cape Town: 336-349.

Situmeang T H. 2008. Analisis Produksi, Konsumsi dan Harga Cengkeh Indonesia. Skripsi. Institut Pertanian Bogor.

Suprihanti, A. 2016. The Agribusiness Dynamics of Indonesian Cigarettes and Its Implication on Tobacco and Clove Market. Proceeding International Conference Strengthening Indonesia Agribusiness: Rural Development and Global Market Linkages. Bogor Indonesia 25-26 April 2016: 33-41.

Tarmidi, L. T. 1996. Changing Structure and Competition in the Kretek Cigarette Industry. Buletin of Indonesian Economic Studies. 32 (3): 85-107.

Tempo. 2015. Konsumsi Rokok Dunia Terus Meningkat. http://koran.tempo.co /konten/ 2015/09/30/383972/KonsumsiRokok-Dunia-Terus-Meningkat

UN Comtrade. https://comtrade.un.org/data/

Wachjutomo, A. 1996. Analisis dampak Kebijakan Pemerintah terhadap Penawaran dan Permintaan Cengkeh di Indonesia. Tesis (Unpublished). Institut Pertanian Bogor. 